\title{
SURFACE PURITY EFFECT ON IRREGULARITIES OF CHANGES IN DEFORMATION TEXTURE OF Zr-2.5\% Nb ALLOY
}

\author{
Dmitry G. Malykhin ${ }^{\mathrm{a}, *}$, Kostiantyn V. Kovtun $^{\mathrm{c}}$, (D)Tetiana S. Yurkova ${ }^{\mathrm{a}}$, \\ (DViktor M. Grytsyna ${ }^{a}$, Gennadiy P. Kovtun ${ }^{\mathrm{a}, \mathrm{b}}$, Iryna G. Tantsura ${ }^{\mathrm{a}}$, Volodymyr D. Virych ${ }^{\mathrm{a}}$, \\ Yuri V. Gorbenko ${ }^{\text {a }}$, (D) Victor M. Voyevodin ${ }^{\mathrm{a}, \mathrm{b}}$ \\ ${ }^{a}$ NSC "Kharkiv Institute of Physics \& Technology" NASU, Kharkiv, 61108, st. Akademicheskaya 1, Ukraine \\ ${ }^{b}$ V.N. Karazin Kharkiv National University, Kharkiv, 61022, Svobody Sq. 4, Ukraine \\ ${ }^{c}$ Public enterprise «NTC «Beryllium», NASU, Kharkiv, 61108, st. Akademicheskaya 1, Ukraine \\ *Corresponding Author: dmitr.malykhin@gmail.com
}

Received September 16, 2020; revised November 9, 2020; accepted December 5, 2020

This work is a continuation of a series of works on the study of regularities and structural mechanisms of changes in characteristics of crystallographic texture during cold deformation of plates made of $\mathrm{Zr} 2.5 \% \mathrm{Nb}$ alloy. Effects of influence of surface cleanliness of the plates on the textural regularities during their rolling were investigated. For this, longitudinal fragments of the tube $\varnothing 15.0 \times 1.5 \mathrm{~mm}^{2}$ were used, flattened, annealed at $580^{\circ} \mathrm{C}$ in a vacuum of 1.5...3.0 Pa and rolled along the axis of the original tube with various degrees deformation up to $56 \%$, which is likened to longitudinal rolling of plates. Techniques of maximally uniform straightening of tube fragments were used. An analysis of the results of studies of textural changes during cross rolling of plates, straightened from rings of the same tube and pretreated under similar conditions, is also carried out. To analyze the results, the method of inverse pole figures was used, which, in these studies, is distinguished by the possibility of achieving satisfactory accuracy in calculating the integral characteristics of texture. On this basis, the Kearns textural coefficient was calculated along the normal to the plates' plane. Corrections were introduced for texture dissimilarity along the thickness of the plates, which is caused by the unbending of the preliminary blanks. Additionally, the analysis of texture distributions was carried out using original techniques. According to the results obtained - as a result of X-ray measuring from the plates' surface - oscillations of the course of changes in the texture coefficient were revealed. This is associated with an alternating process of relaxation of residual stresses during deformation. It has been established that this effect is initiated from the near-surface regions, is associated with a near-surface impurity, and in some cases can penetrate to a considerable depth of the plates. The twinning nature of such regularities is confirmed and active systems of twins are noted.

KEYWORDS: zirconium alloys, rolling, X-ray diffraction, texture, stresses, twinning.

This work is a supplement to the cycle of X-ray studies of regularities of changes in the crystallographic texture during cold deformation of zirconium and its alloys [1-3]. A feature of such works is the implementation of X-ray studies of rolling textures from their moderate level and the use of the method of inverse pole figures (IPFs) with an increased accuracy of determining the quantitative texture characteristics.

In the course of the research, a task was formed to study an effect of stress relaxation in $\mathrm{Zr}-2.5 \% \mathrm{Nb}$ alloy, expressed in the instability of the process of texture changes after deformation, as well as to analyze conditions for manifestation of this effect. Preliminary studies have established that this effect is initiated on the surface of deformed plates [4]. Comparison of the results of works [2-4] gives reason to assume that this is due to surface impurities. Such a circumstance can occur under usual conditions of materials machining.

In view of this, this work is aimed at continuing the study of stress relaxation effects associated with the state of surface of hcp metals of the titanium subgroup. It is focused on the X-ray study of structural mechanisms of deformation, directly related to stress relaxation, and also on conditions of its manifestation. The results obtained can contribute to study of laws of plastic deformation of hcp metals used in nuclear, aircraft, aerospace engineering and medicine.

The main subject of the research is the Kearns texture parameter (TP) [1,2,5]. Many characteristics of zirconium alloys and other metals with hcp lattice are associated with it. According to changes in this parameter with the degree of deformation by rolling of alloys and using other methods, the analysis of textural dynamics - redistribution of the crystallographic axes " $c$ " of the material and characteristic features of such changes - is provided.

\section{EXPERIMENTAL}

For the research, the material of $\varnothing 15.0 \times 1.5 \mathrm{~mm}^{2}$ tube of $\mathrm{Zr}-2.5 \% \mathrm{Nb}$ alloy was used. The measurements of texture characteristics were performed on the DRON4-07 X-ray diffractometer in $\mathrm{CuK} \alpha$ radiation with the Bragg-Brentano scheme.

According to preliminary studies, the texture of the tube turned out to be similar to the usual rolling texture of plates which rolling direction coincides with the tube axis [2]. A distinctive feature was its fan-like shape - the moderate character of its distribution along cross section of the tube.

Sample blanks were cut from the tube in the form of longitudinal fragments. Further, they were straightened to flat shape. To straighten them as uniformly as possible, they were deformed using tubes of different diameters.

After that, the obtained plates were annealed at $580^{\circ} \mathrm{C}$ for 24 hours in a vacuum of $1.5 \ldots 3.0 \cdot 10^{-3} \mathrm{~Pa}$. Further, the plates were deformed by cold rolling within $6 \ldots 55 \%$ along their length. The degree of deformation from sample to (C) D. G. Malykhin, K. V. Kovtun, T. S. Yurkova, V. M. Grytsyna, G. P. Kovtun, I. G. Tantsura, V. D. Virych, Y. V. Gorbenko, V. M. Voyevodin, 2021 
sample was achieved in one act. Up to $40 \%$ of the total deformation, this was carried out with a step of $6 \ldots 10 \%$. Technological breaks were made between the acts of rolling from ten to forty minutes for size measurements. As a result, a series of 6 samples was obtained. In view of the texture feature of the original tube, the deformation of the plates was considered as longitudinal rolling.

The investigated surfaces of the plates were etched by $10 \ldots 15 \mu \mathrm{m}$ in a reagent with a volumetric combination of water, nitric and hydrofluoric acid in a ratio of 9:5:1.5.

We also present and analyze the results of studies of plates straightened from rings of the same tube, with similar preparation conditions, including the degree of rolling with other details, and subsequent etching [4]. In view of the texture feature of the original tube, deformation for this series of samples was considered as cross rolling.

Texture of the plates was investigated by the method of inverse pole figures (IPFs) [6]. The essence of the method is to analyze quantitative proportions in (hkil) crystallographic orientations of hep lattice of the material along selected direction of sample. In this case, this is the direction of the normal to its surface. An analogue of this distribution is the density of poles $\left(P_{h k i l}\right)$, which was determined from the intensities of the recorded X-ray reflections $(h k i l)$ with certain normalization: it should give the value of unity for all (hkil) in case of a textureless material.

The texture parameter (TP) is calculated using the obtained set $\left\{P_{i}\right\}$ [7]:

$$
f_{j}=\left\langle\cos ^{2} \alpha_{i}\right\rangle_{j}=\sum_{i} A_{i} P_{i j} \cos ^{2} \alpha_{i}
$$

where $\alpha_{i}$ is the angle between the base normal of reflecting grains - this is "c" axis of hep cell - and the measurement direction $(j)$, normal to the plate plane $(\mathrm{NN}) ; A_{i}$ is statistical weight of $i$-th reflection - solid-angular size of the neighborhood related to $i$-th crystallographic orientation of grains [7].

In order to take into account the texture differences between the sides of the plates - the outer and inner surfaces of the original tube - the measurements were made from both sides. In this regard, the appropriate designations were adopted: "front" and "back" side of the plates.

As a result of repeated measurements of cross-rolled plates, satisfactory texture homogeneity was noted on the surfaces of the tube and the plates (this is reflected in the subsequent graphs). In this case, in determining the TP $(0 \leq f \leq 1)$, the random error as a whole was \pm 0.003 . Systematic error may have an increased value due to texture inhomogeneity along the plate thickness.

\section{RESULTS AND DISCUSSION}

Figure 1a,c shows the TP values on the both sides of the alloy plates for each degree of longitudinal and cross deformation. Significant differences are observed in the data measured from different sides of the plates.
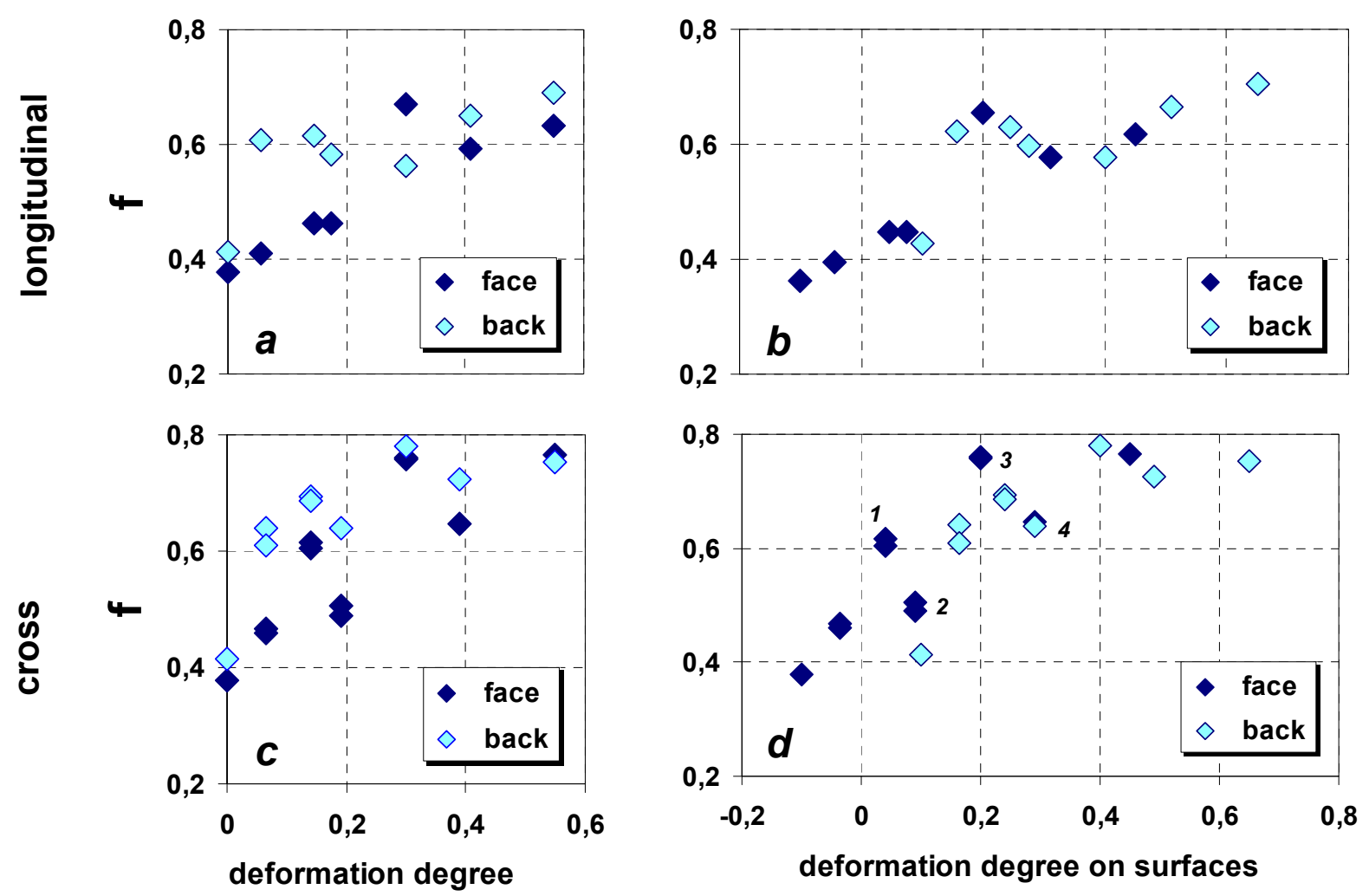

Figure 1. TP changes with degree of deformation by longitudinal (a, b) and cross rolling (c, d; [4]) of Zr-2.5\% Nb alloy plates $(a, c)$ and near-surface layers on their both sides $(b, d)$. 
According to the experience of work [2,4], the deformation degrees were corrected taking in account its inhomogeneity along the thickness of the plates. The correction was calculated based on the values of the thickness and diameter of the original tube - and was introduced as a deformation of the medium on the surface of the original plates similarly to rolling. As a result, more regular graphs of TP changes with deformation of the plates medium were obtained (Fig. 1b,d). For graph 1b, the optimal regularity was achieved by additionally introducing a correction of $\pm 0,015$ to the TP values ("-" for the front side). The numbers in Figure $1 \mathrm{~d}$ refer to the following discussion.

As a result, as in the case of cross rolling of plates with specific preparation conditions (see Experimental) [4], during longitudinal rolling of such a material, oscillations in the TP changes are also observed (Fig. 1b). And at the same time, the inaccuracy of introducing corrections to deformation also did not exceed $\pm 0.5 \%$. However, in view of the fact that the both cross rolling and effect of unbending deformation of the original rings act in a single geometric direction, the additivity of introduction of the correction with achievement of optimal regularity of the corresponding graph in this case is quite obvious. As for longitudinal rolling, we will discuss it below.

Visual analysis of Figures 1b,d shows a qualitative coincidence of the features of the graphs in the neighborhood of $\varepsilon=0.1$ ( $10 \%$ deformation on the surfaces). Following the conclusions of work [4], this feature can be directly attributed to the relaxation of viscoelastic stresses which remained after annealing of straightened blanks and affected texture of the material. Further in Fig. 1b, there is an oscillation of TP with a period of $\Delta \varepsilon \approx 0.4(40 \%)$, while for cross rolling (Fig. 1d) this period is approximately 0.2 . We will also discuss these details below.
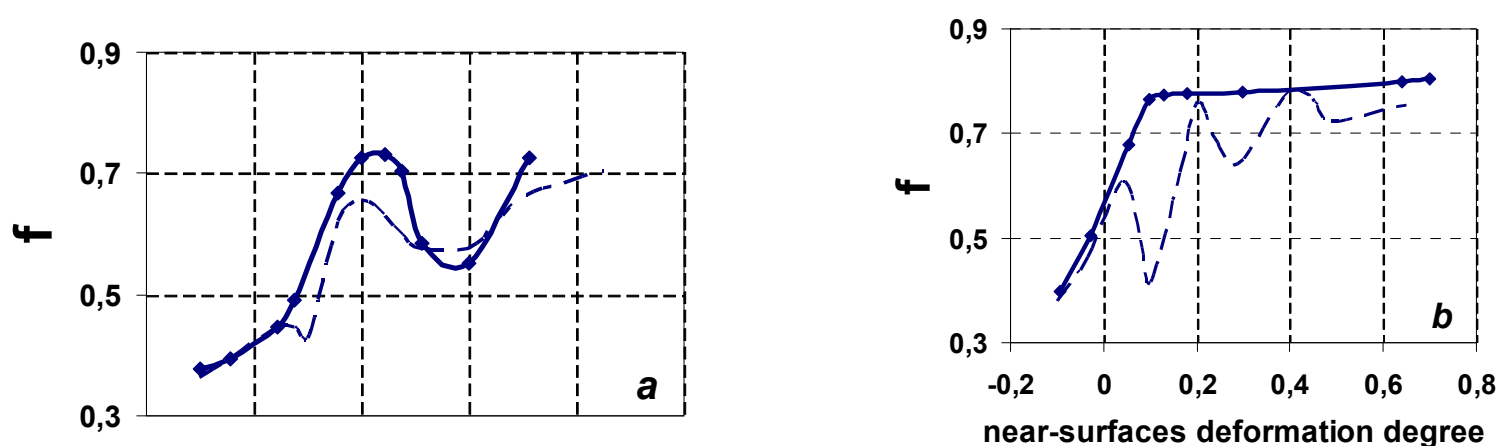

Figure 2. Changes in graphs of TP dependence on degree of longitudinal (a) and cross rolling (b [4]) after etching of the plates to a depth of $\approx 30 \mu \mathrm{m}$ (solid lines)

As mentioned at the beginning and noted in [4], TP oscillations during cross rolling of plates are associated with relaxation of residual stresses, and it is initiated on the surfaces of the plates. Comparing the conditions of sample preparation in the present studies and in [2,3], we can conclude that the surface relaxation of residual stresses, expressed in the effect of oscillations, is associated in this case with interstitial impurities on the surface of deformed samples. In this case, the nature of the data obtained during longitudinal rolling, first of all, gives grounds to clarify two points: how significant is the relaxation of stresses in changes in TP in the free state of the plates (for example, during half an hour); what are the limits of propagation of the TP oscillation effect into the depth of the plates.

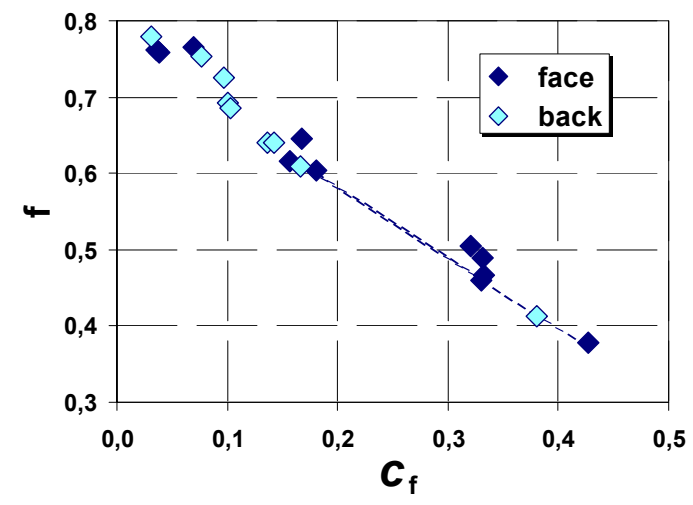

Figure 3. Relation of TP values with content of fraction could be twinned by cross rolling of plates

As for the first point, the idea of stress relaxation in the periods between the acts of cross rolling of the plates was induced by a "reverse" in the changes in TP on their front surface, which manifested itself almost in every act (Fig. 1d) [4]. However, during longitudinal rolling (Fig. 1b), this character is not felt so clearly, and with increased deformations, the experimental points fit into a sinusoid with a doubled period, which does not give grounds to consider free relaxation to be a significant effect of TP changes.

As for the second point, i.e. the depth of propagation of the relaxation effect, then in [4] it was noted that on the front surface of cross-rolled plates the effect was limited to $30 \mu \mathrm{m}$ depth. At the same time, the irregularity effect partially remained on the back side.

This study is supplemented with results obtained for longitudinally rolled plates with similar preparation conditions, etched up to $65 \mu \mathrm{m}$ (Fig. 2a, solid lines). Dashed lines in Figure 2 mark the initial graphs (Fig. 1b, d).

According to Figure 2a, in longitudinally rolled plates, the effect of irregularity of the TP graph, associated with textural effect of stress relaxation, penetrates to a considerable depth on both sides of the plates.

Following the approaches provided in $[2,3]$, the analysis of the relationship between changes in TP and the distributions of orientations of the crystallographic axes " $c$ " under conditions of stress relaxation in deformed plates of the alloy was carried out. The data obtained is shown here for cross rolling.

In particular, the participation in such changes of the fraction of grains could be twinned during deformation is analyzed. Figure 3 shows a comparison of TP (Fig. 1c,d) with the relative portion $\left(C_{f}\right)$ of such a fraction. 
The graph on Fig. 3 repeats the character inherent in deformed alloy plates prepared under normal conditions [2], i.e., practically, in absence of both residual stresses and the effect of their relaxation.

Thus, in relation to the effect of TP oscillations, the conclusion is repeated that twinning is significantly dominant in this process. In this case, all the points lying on the drawn straight line (Fig. 3) refer to the intervals of TP increase (Fig. 1d) and indicate the exclusive activity of the $\{10 \overline{1} 2\}[1011]$ system of tensile twins with participation possibly of $\{1 \overline{2} 1\}[\overline{1} 126]$ system [8]. Their combination rotates the " $c$ " axes by an angle $\approx 90^{\circ}$, which gives the derivative for the straight line equal to -1 .

The points located above the straight line (Fig. 3) refer to the TP return intervals (Fig. 1b,d). They are probably associated with compression twins, which do the counter-rotation of " $c^{\prime \prime}$ axes at an angle $\approx 60^{\circ}$ [8] (derivative $>-1$ ). To confirm this, Figure 4 shows the graphs of the pole density distribution on the base of $(h 0 \bar{h} l)$ reflections. It is given for $14 . . .39 \%$ of cross rolling in a logarithmic scale and represented by $\cos ^{2} \alpha$ (Fig. 4a). Figure $4 \mathrm{~b}$ shows similar distributions for usual conditions of sample preparation - without the TP oscillations [3]. The both figures refer to the face of the plates. The graphs in each figure are located with arbitrary intervals along the ordinate axis.
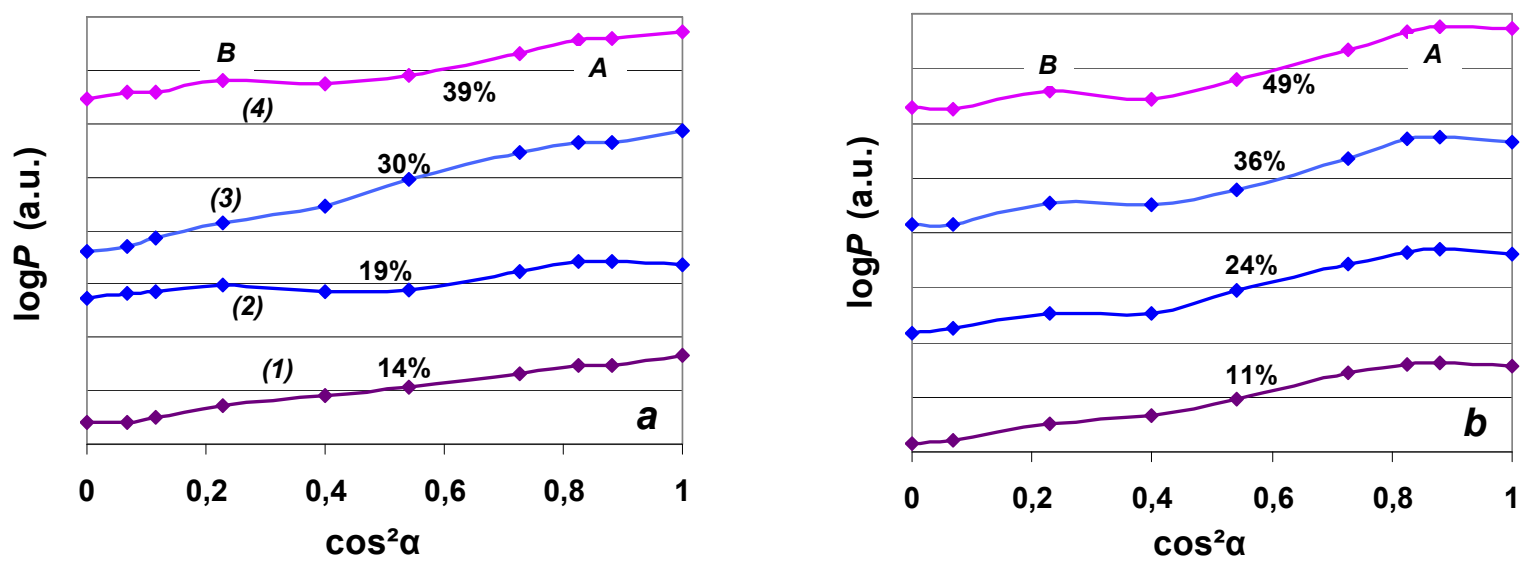

Figure 4. Density distribution of poles $P_{(h 0}$ l) for deformed alloy plates in conditions of stress relaxation effects (a) and without it (b [3]).

A characteristic basis of the graphs in Figure $4 \mathrm{~b}$, as also was noted in [1,3], is their linear course. The conditional maxima at points $A$ and $B$ were associated with twinning effects. The rising of the graphs in the neighborhood of point $A$ $\left(\cos ^{2} \alpha \approx 1 ; \alpha \approx 0\right)$ was associated with the result of action of tensile twins on the base of the $\{10 \overline{1} 2\}[1011]$ system. Point $B$ was associated with reverse rotations of the " $c$ " axes at an angle $\Delta \alpha \approx 60^{\circ}\left(\cos ^{2} \alpha \approx 0.25\right)$ created by compression twins.

The qualitative difference in Figure $4 \mathrm{a}$ is manifested in the oscillations of the character of the graphs from one to next, which uniquely accords with the TP oscillations in Fig. 1d; (marked with the corresponding numbering "1"-"4").

In view of the foregoing, the TP oscillations, like any its changes in the deformation process [3], are associated with twinning effects. In this case, this is a mutually counter-directional alternating action of both classes of twins: compression twins - it can be particularly seen from the local rise of graphs (2) and (4) in the neighborhood of point $B-$ and tensile twins, what is expressed in the rise of graphs (1) and (3) in the neighborhood of $A$ (Fig. 4a).

It can reasonably be argued that independent action of each of the two classes of the twins begins with reaching a certain threshold level in the distribution of initiating stresses (lattice distortions) between these classes, and ends with a reverse redistribution, giving rise to another class. In this case, just as in [3], the turns of " $c$ " axes mainly occur along the fan of their orientations, which is inherent in the texture of the original tube. This was established as a result of the analysis of the rocking curves of the deformed plates. This justifies the principle of introducing deformation corrections when obtaining graph $1 \mathrm{~b}$ : when straightening the blanks and subsequent deforming of the plates, the crystallographic rotations of the grains are carried out in a single plane. This is the cross-sectional plane of the original tube. However, in view of the existing differences in the rates of TP changes during deformation by longitudinal and cross rolling (with a multiplicity of 1:2 [2]), it remains unclear why such a correction for longitudinal rolling is equal to 0.1 , not 0.2 . In this regard, it remains to formally state that under conditions of accumulation of viscoelastic stresses during straightening of the blanks, longitudinal rolling initially sets its own regularity to TP changes.

Taking into account the conditions and features of the accumulation of residual stresses and the manifestation of the effect of their relaxation, it can be concluded that surface purity plays a role in this.

Obviously, it makes no sense to assume that only the main acting twins, and, consequently, other twins, play an immediate role in the stress accumulation. It remains to attribute the stress accumulation effects to the influence of surface impurities directly on gliding processes. This is mainly the effect of oxygen, the concentration of which on the surface of the initial plates exceeded $0.2 \mathrm{wt} \%$ in this experiment and was limited to $0.14 \mathrm{wt} \%$ in $[2,3]$.

Although under normal conditions of deformation, twinning and prismatic gliding in hep metals of the titanium subgroup act simultaneously and in a balanced manner, there is reason in these studies to consider twinning as more active. This can explain the feature of the initial changes in TP in Figure $2 b$ (solid line; cross rolling [4]), the rate of which, according to [3], should be considered, as well as in Fig. 1d [3], overestimated by about two times. Obviously, 
despite the significant elimination of the surface layer in the alloy plates, the influence of the surface contamination effect on the deformation texture extends beyond the near-surface layer. This is especially confirmed by Fig. $2 \mathrm{a}$.

\section{SUMMARY}

Surface effects of stress relaxation in the plates made from a $\mathrm{Zr}-2.5 \% \mathrm{Nb}$ alloy tube $\varnothing 15.0 \times 1.5 \mathrm{~mm}^{2}$ have been studied using the X-ray method of inverse pole figures (IPFs). Effects of oscillations of texture characteristics at cold deformation of plates by longitudinal and cross rolling have been investigated. The following results have been obtained.

The oscillations of the Kearns' texture parameter with degree of deformation of alloy plates are associated with a mutually counter-directional alternating action of tensile and compression twin classes.

The sequence of the action of twins is associated with the threshold effects of stress accumulation in the material, which is due to the near-surface impurity and its influence on the microstructural gliding processes.

When the plates are deformed in the presence of impurities, the activity of twinning systems is increased, which has a significant effect on the characteristics of texture changes.

Influence of surface impurities on the process of texture changes can extend to a significant depth of the material.

\section{ORCID IDs}

(DDmitry G. Malykhin, https://orcid.org/0000-0003-0259-0211; (D Kostiantyn V. Kovtun, https://orcid.org/0000-0002-0524-5053

(D)Tetiana S. Yurkova, https://orcid.org/0000-0003-1264-640X; DViktor M. Grytsyna, https://orcid.org/0000-0003-4341-007X

(1)Gennadiy P. Kovtun, https://orcid.org/0000-0003-4242-7697; (DVictor M. Voyevodin, https://orcid.org/0000-0003-2290-5313

\section{REFERENCES}

[1] G.P. Kovtun, K.V. Kovtun, D.G. Malykhin, T.S. Yurkova, and T.Yu. Rudycheva, East Eur. J. Phys. 4(3), 44-50 (2017), https://doi.org/10.26565/2312-4334-2017-3-05.

[2] V.M. Grytsyna, D.G. Malykhin, T.S. Yurkova, K.V. Kovtun, T.P. Chernyayeva, G.P. Kovtun, V.V. Kornyeyeva, O.O. Slabospitskaya, I.G. Tantsura, and V.N. Voyevodin, East Eur. J. Phys. 2, 39-45 (2019), https://doi.org/10.26565/23124334-2019-2-06.

[3] V. Grytsyna, D. Malykhin, T. Yurkova, K. Kovtun, T. Chernyayeva, G. Kovtun, I. Tantsura, V. Voyevodin, East Eur. J. Phys. 3, 38-45 (2019), https://doi.org/10.26565/2312-4334-2019-3-05.

[4] V.M. Grytsyna, D.G. Malykhin, T.S. Yurkova, K.V. Kovtun, T.P. Chernyayeva, G.P. Kovtun, and V.N. Voyevodin, Problems of Atomic Science and Technology, 5(117) 69-74 (2018), https://vant.kipt.kharkov.ua/ARTICLE/VANT_2018_5/article_2018_5_69.pdf.

[5] J. Kearns, Thermal expansion and preferred orientation in Zircaloy, USAEC WAPD-TM-472, (Westinghouse Electric Corporation, Pittsburg, Pa. USA, 1965).

[6] G.B. Harris, Quantitative measurement of preferred orientation in rolled uranium bars, Phil. Mag. 43(336), 113-123 (1952), https://doi.org/10.1080/14786440108520972.

[7] P.R. Morris, J. Appl. Phys. 30(4), 595 (1959), https://doi.org/10.1063/1.1702413.

[8] E. Tenckhoff, J. ASTM Int. 2(4), 1-26 (2005), https://doi.org/10.1520/JAI12945.

\section{ЕФЕКТ ЧИСТОТИ ПОВЕРХНІ У НЕРЕГУЛЯРНОСТЯХ ЗМІН ТЕКСТУРИ ДЕФОРМАЦІЇ СПЛАВУ Zr-2.5\%Nb} Д.Г. Малихін ${ }^{\text {a }}$ К.В. Ковтун ${ }^{\mathrm{c}}$, Т.С. Юркова ${ }^{\mathrm{a}}$, В.М. Грицина ${ }^{\mathrm{a}}$,

Г.П. Ковтун ${ }^{\mathrm{a}, \mathrm{b}}$, І.Г. Танцюра ${ }^{\mathrm{a}}$, В.Д. Вірич ${ }^{\mathrm{a}}$, Ю.В. Горбенко ${ }^{\mathrm{a}}$, В.М. Восводін ${ }^{\mathrm{a}, \mathrm{b}}$

${ }^{a}$ ННЦ «Харківський фізико-технічний інститут» НАНУ, Украйна, 61108, г. Харків, ул. Академічна 1

${ }^{b}$ Харківский наиіональний університет ім. В.Н. Каразіна, Украйна, 61022, м. Харків, майдан Свободи, 4 сДП «НТЦ «Берилій» НАНУ, Україна, 61108, м. Харків, вул. Академічна 1

Дана робота є продовженням циклу робіт з досліджень закономірностей і структурних механізмів змін характеристик кристалографічної текстури при холодній деформації пластин зі сплаву $\mathrm{Zr} 2,5 \% \mathrm{Nb}$. Досліджувалися ефекти впливу чистоти поверхні пластин на закономірності текстурних змін у процесі їх прокатки. Для цього використано поздовжні фрагменти труби $\varnothing 15.0 \times 1.5 \mathrm{mм}^{2}$, які випрямлені до плоскої форми, відпалені при $580^{\circ} \mathrm{C}$ у вакуумі $1,5 \ldots 3,0$ Па і прокатані уздовж осі вихідної труби з деформацією різних ступенів до 56\%, що вважалося аналогічним поздовжній прокатці пластин. Використано прийоми максимально рівномірного випрямлення фрагментів труби. Проведено також аналіз результатів досліджень текстурних змін при поперечній прокатці пластин, випрямлених з кілець такої ж труби і попередньо оброблених в подібних умовах. Для аналізу результатів використано метод зворотних полюсних фігур, що відрізняється в даних дослідженнях можливістю досягнення задовільної точності розрахунку інтегральних характеристик текстури. На цій основі проведено розрахунок текстурного параметру Кернса уздовж нормалі до площини пластин. Введено поправки на текстурну неоднорідність вздовж товщини пластин, що пов'язано з розгинанням попередніх заготівок. Додатково проведено аналіз текстурних розподілів із застосуванням оригінальних прийомів. Згідно з отриманими результатами - в результаті зйомок 3 поверхні пластин - виявлено осциляції ходу змін текстурного параметра. Осциляції зв'язуються зі знакозмінним процесом релаксації залишкових напружень в процесі деформації. Встановлено, що цей ефект ініціюється з приповерхневих областей, пов'язаний $з$ приповерхневою домішкою і в деяких випадках може проникати на значну глибину пластин. Підтверджено двійникову природу таких закономірностей і відзначено активні системи двійників.

КЛЮЧОВІ СЛОВА: цирконієві сплави, прокатка, рентгенографія, текстура, напруження, двійникування. 